\title{
Socio-economic Consequences of Globalization in Agriculture in Relation to Social Responsibility
}

\author{
Hana Polackova* \\ University of Economics in Bratislava, Faculty of National Economy, Dolnozemska cesta 1, 85235 \\ Bratislava, Slovak Republic
}

\begin{abstract}
Agriculture has allowed for people to settle in one place and stop moving for food. It made possible to survive and later trade. Agriculture was the main driver of the economy since the creation of the first states to the 20th century. In today's globalized world, we consider an economically successful country where the industry dominates. Industry, compared to agriculture, offers greater opportunities for growth in gross domestic product. In addition to economic cycles, economic activities closely related to agriculture are also affected by climate fluctuations, pests, diseases, inadequate crops and others. Despite the fact that agricultural output is essential for life, agriculture has been on the second track. The stability and sustainable development of a country depends on the influence of various economic, non-economic and political factors. However, the low elasticity of agricultural production supply, dependence on natural conditions and the limited durability of production results can make agriculture a weak link in planning the further development of the country's economy. The paper deals with the need for a socially responsible approach to agriculture and the identification of factors that can affect the stability of the economy, the sustainability of economic growth as well as the health of the population and the environment. Information for the preparation of this paper was drawn from the data of the Statistical Office, expert studies and economic literature. At the end of the paper is outlined the possible use of agriculture as a major industry in the context of solving some social problems.
\end{abstract}

\section{History as an introduction to the issue}

Agriculture is a basic milestone in the socioeconomic development of civilization and the oldest of economic sectors. Improving technology for the cultivation and processing of agricultural products and the preservation of foods has enabled population growth and the development of other sectors. Other economic activities - crafts, trade - could only develop in a country that had a steady and sufficient supply of food assured. The growth of labour productivity in agriculture also enabled the freeing up of the labour force for the establishment of armed forces. The primary aim of states was self-sufficiency in food

*Corresponding author: hana.polackova@euba.sk 
production, especially due to the technological limitations of production, transport and storage of agricultural commodities. For centuries agriculture employed the most people. Survival of all layers of citizenry - rulers, priests, government officials, soldiers, craftsmen and merchants - depended on the production of peasants. Up to the 20th century agriculture was the primary driving force of the economy in the vast majority of countries. Evidence of the importance of agriculture also lies in the fact that its products served as forms of payment. The first wave of civilization - the agriculture one - was gradually replaced by industrial civilization in the 16th to 18th centuries. Just a few decades were needed, however, for industry to push agriculture to the sidelines. The situation has become so acute that at present there is an effort to replace food, originally made by processing local plant and animal products, with synthetic proteins made neither from plant, nor animal tissues. This phenomenon is also addressed by J. Ikerd in his article The future of food: Separation or integration?, [1] where he deals with the issue of the future of food and agriculture whether agriculture can be separated from nature and society. He points to the influences of industrially produced foods for public health and asks questions about food safety and the nutritional value of today's foods.

Agriculture was pushed to the background for the first time by mercantilists, who from the start of the new age to the mid-18th century favoured the production sector and foreign trade with the goal of acquiring precious metals and thus increasing the wealth of the country. In the 18th century the French physiocrat movement, which saw the source of wealth in agriculture, responded to the situation. The subsequent agricultural revolution led to a better supplied market in foods and liberated the labour force from agriculture. Thus, it created the conditions for the start of the Industrial Revolution. The "classic" economist of the Industrial Revolution, David Ricardo (1772 - 1823), saw the wealth of nations in the division of labour and free trade [2]. His theory of comparative advantages changed the economic policy of countries and influenced world trade. From the mid-1840s, a national direction began to develop in the economy in Germany. Its adherents claimed that the classic English economy is not universally applicable to all countries, since each country has different religious, cultural and historical roots. In the case of an industrially undeveloped economy, they were more inclined toward a temporary protectionist trade policy. Contrary to classic economics, in their opinion the state plays a leading position, and the interests of individuals must be subordinated to social interests. Economics should deal with the analysis of economic and social life in order to achieve a social objective.

Despite the significant transformation of European agriculture, which was able to increase work productivity with modern technologies, at the start of the 20th century a dependence on the import of agricultural commodities began to be seen. Before 1870 parts of Europe specialized in their own products and Europe was self-sufficient. After 1870 the population grew significantly, and a large part of the labour force began to take advantage of work opportunities in industry. Problems began to appear when declining yields from a range of grain products (around the year 1900) caused purchasing power to be greater than the amount of food. The agrarian-industrial economies were transformed into industrialagrarian ones. Several countries had to start securing the means of subsistence abroad and became dependent on overseas trade of food supplies. A significant breakthrough in trading food occurred with the speeding up of transport and the use of efficient refrigeration equipment for the transport of perishable foodstuffs over long distances. Different areas of the world began to be agriculturally and food dependent and commercially connected to one another. 


\section{Particularities of agriculture, risk factors and risk trends}

We cannot survive without agricultural products. Agriculture as a source of income for businesses can relatively easily become unprofitable, since agricultural production has certain particularities when compared with industrial production.

\subsection{From the viewpoint of the producer we can classify the following as risk factors:}

- The amount and prices of production are derived from natural conditions, the number of pests and diseases.

- The low flexibility of production on offer.

- Negative externalities and production rejected by the public in a certain location (demand for water, odours).

- Unsuitable agrarian policy.

- Tighter conditions for the use of pesticides for eliminating pests, moulds and weeds.

- Diseases and mortality of bees.

- Serious manifestations of climate change, which can also have a negative impact on the amount and quality of production of agricultural land.

The integration of social but above all ecological viewpoints into the common functioning of agricultural firms will be complicated, however, in relation to the dependence of producers in less developed countries on the amount of agricultural production. In 2019 a collection of authors published the results of a study in association with economic and ecological perspectives of farmers from the viewpoint of using pesticides when cultivating rice. [3] Despite the fact that $76 \%$ of the Philippine respondents acknowledged the negative effects of pesticides on the environment, local farmers had still decided to use expensive pesticides. Increased yields and incomes of small farmers took precedence over social responsibility. The only path away from the dependence of these farmers on pesticides would be an effective, safe and inexpensive means of pest control. The matter of Corporate Social Responsibility is dealt with by E. Pongracz. [4,5]. A team of researchers in France studied the impact of long-term climate changes and land use on aphid abundance. The results of their research demonstrated that climate change is having a significant effect on the aphid population. [6] The question then arises of whether the use of pesticides will increase with climate change. The amount of $\mathrm{CO}_{2}$ in the atmosphere, which is also released from the soil by intensive agriculture and irrigation, has an effect on climate change. Research on unprofitable abandoned agricultural areas in Mallorca showed that the volume of carbon bound in the soil began to increase in such soils. The authors concluded that a change in agricultural practices may contribute to the recapturing of atmospheric $\mathrm{CO}_{2}$ carbon in the soil. [7] However, not all people bear equal responsibility for climate change. The poor will suffer the impacts of climate change disproportionately with respect to their modest contribution to it. The question of social justice in climate risk management and interventions involving compromises in tackling climate change are dealt with by the authors of the paper Index insurance and climate risk management: Addressing social equity. [8] The authors of a study on the production of soy and beef address the restructuring of agriculture in South America in connection with a change in environmental regulations. They come to the conclusion that a local regulatory change was insufficient and did not have the anticipated effect, since importers had merely changed their channels of trade and moved from exporters with the most stringent regulations to supplies from local markets. [9] 


\subsection{From the viewpoint of households, structural changes in the economy may be detrimental to agricultural production:}

- The impossibility of finding work in the countryside.

- Self-insufficiency in food production and dependence on food imports (risk of rising prices and thus rising food expenditure with unchanged household income) in extreme cases food shortages.

- Inadequate structure of agricultural crops (the dominance of technological crops) may mean shortages of staple foods.

- Import of poor quality food (technical salt in food, the pesticide fipronil in eggs, meat with salmonella...).

- Inexpensive imported food may also mean the disappearance of agricultural production and domestic animal husbandry even in rural households, low domestic natural consumption, and the loss of the older generations' skills, knowledge and experience from ancestral farms.

- In low-income households, the favouring of product price over product quality, which may have a negative impact on the health of members of society.

R. Lencucha and A. M. Thow analyse in their article How Neoliberalism Is Shaping the Supply of Unhealthy Commodities and What This Means for NCD Prevention the role of policy makers in addressing public health issues and non-communicable diseases. The consumption of unhealthy foods also contributes significantly to non-communicable diseases (NCD). One of their proposals is, in place of regulating such foods to create a healthy product environment, to promote agribusiness and solve supply-side problems. [10]

\subsection{Risks from industrial or industrial-agrarian farming from a macroeconomic point of view:}

- The disappearance of traditional agricultural and related sectors.

- The disappearance of local agricultural products.

- Structural unemployment; by importing production that could be produced in the home country, job opportunities are given to foreign labour abroad.

- The risk of social unrest if there are food shortages and the inability to import foodstuffs.

- Strategic risk in case of war.

- Environmental risks (e.g. large-scale cultivation of rapeseed has a negative impact on territorial animals, to which the consumption of rape causes serious health damage or death).

- The risk of easier transmission of diseases and pests due to low diversity and narrow specialization in fewer agricultural products.

- Rural depopulation.

- Passive trade balance in imports of agricultural and food products.

\section{The involvement of the Slovak Republic in international trade with agricultural products}

In Central and Eastern Europe in the 20th century, developments in the agricultural sector were influenced by collectivization carried out on the principle of central planning, where quantity became the main objective, while quality and efficiency only were of secondary importance. [11] Unsuitable agrarian policies, nationalization and land consolidation led to 
a disruption of relations and connections of the population to agricultural land. Paradoxically, after the transformation of these economies to market economies, problems in agriculture are beginning to cause fragmentation of land ownership and complications in user relations. Slovakia is a small non-self-sufficient open economy, which is very much influenced by the development of world agricultural commodity prices, as well as energy raw materials, in particular oil. Thanks to international trade it is possible to import cheaper (even though sometimes inferior) food, but at the cost of sacrificing food self-sufficiency, food security and jobs that could be created in agriculture.

According to data from the Slovak Ministry of Agriculture and Rural Development from Information on foreign trade development of the Slovak Republic in agricultural and food products in 2017, Slovakia traded with more than 70 countries from around the world in addition to $27 \mathrm{EU}$ countries. [12] Overall imports increased year-on-year from 2016 to 2017 from 4104.3 to 4238 mil. euros. Even though exports increased slightly in 2017, imports increased more, and according to the ministry's data, the negative balance of trade increased by 124.3 mil. euros to a total value of -1.4 billion. [13] The low share of Slovak agricultural products in the domestic trade network is also caused by the low profitability of agricultural production. The sector is undersized financially when compared with neighbouring countries, and so it cannot compete with cheaper foreign production in a globalized world. According to N. Jankelova, D. Masar and S. Moricova (2017), [14] Slovak farmers perceive price risk, production risk and income risk as the most important risk factors. Furthermore, low average wages in Slovakia are one of the reasons why the Slovak customer prefers a low price over higher-quality, but more expensive Slovak products. P. Serences, Z. Cierna and A. Piterkova (2016) address the issue of development of agricultural efficiency in their article. [15] The advantage of domestic Slovak food production lies in that it is not burdened by any food scandal.

\section{Conclusion}

We can see the impacts of globalization on agriculture and food security from different angles. Not all findings may be positive, however. If we look through the optics of specialization and international trade - the amount of pollutants that are released into the air during the necessary transport of goods - contributes to the disruption of ecosystems and the climate around the world. The results of this are ever more frequent climatic fluctuations and extreme weather events - droughts, floods or torrential rainfall - which cause arable land to be washed away. The consequent crop failure can have a negative impact on GDP (especially in the case of agrarian countries) and access to food. Secondly, changes in the structure of economies are in favour of production with higher labour productivity and a smaller share of agriculture, which then forces countries to import food. Such a trend is evident in many European countries, including Slovakia.

The sustainability of the economy, competitiveness and food security are therefore conditioned on the responsible approach of society to the sector. It's not necessary to transport products that a country can produce by involving domestic factors of production half-way across the globe. Agrarian policy must satisfy the need of the population to have access to sufficient amounts of quality foodstuffs, to take into account regional differences and to promote the principles of socially responsible business in the area of human rights, labour standards and the environment. Inappropriate measures may result in social unrest and economic and ecological migration.

The contribution arose in the course of implementing the project VEGA no. 1/0367/17 "Economic, legislative and institutional foundations and perspectives for development of a social and collective economy in the V4 countries for the support of social inclusion". 


\section{References}

1. J. Ikerd, The Economic Pamphleteer: The future of food: Separation or integration? Journal of Agriculture, Food Systems, and Community Development, 8, 9-12 (2019)

2. D. Ricardo, Zasady politickej ekonomie a zdanovania. (Pravda, Bratislava, 1980)

3. M.T.N. Cabasan, J.A.G. Tabora, N.N. Cabatac, C.M. Jumao-as, J.O. Soberano, J.V. Turba, N.H.A. Dagamac, E. Barlaan, Economic and ecological perspectives of farmers on rice insect pest management. Global Journal of Environmental Science and Management, 5, 31-42 (2019)

4. E. Pongracz et al., Socialna ekonomika. (Ekonom, Bratislava, 2015)

5. E. Pongracz, Social Economy - An Economy That Focuses on Human Beings as an Expression of Social Responsibility. Proceedings of International scientific conference on Globalization and its Socio-Economic Consequences. Rajecke Teplice, Slovakia, 591-596 (2015)

6. M. Luquet, M. Hullé, J.-Ch. Simon, N. Parisey, Ch. Buchard, B. Jaloux, Relative importance of long-term changes in climate and land-use on the phenology and abundance of legume crop specialist and generalist aphids.Insect Science, 26, 881-896 (2019)

7. J.A.R. Martin, J. Alvaro-Fuentes, J.L. Gabriel, C. Gutierrez, N. Nanos, M. Escuer, J.J. Ramos-Miras, C. Gil, D. Martin-Lammerding, R. Boluda, Soil organic carbon stock on the Majorca Island: Temporal change in agricultural soil over the last 10 years. Catena, 181 284-294, (2019)

8. E. Fisher, J. Hellin, H. Greatrex, N. Jensen, Index insurance and climate risk management: Addressing social equity. Development Policy Review, 37, 581-602 (2019)

9. Y.L.P. de Waroux, R.D. Garrett, J. Graesser, Ch. Nolte, Ch. White, E.F. Lambin, The Restructuring of South American Soy and Beef Production and Trade Under Changing Environmental Regulations. World Development, 121, 188-202 (2019)

10. R. Lencucha, A.M. Thow, How Neoliberalism Is Shaping the Supply of Unhealthy Commodities and What This Means for NCD Prevention. International Journal of Health Policy and Management, 8, 514-520 (2019)

11. P. Adamisin, R. Kotulic, I. Kravcakova Vozarova, Legal form of agricultural entities as factor in ensuring the sustainability of the economic performance of agriculture. agriculture sector. Agricultural Economics - Zemedelska ekonomika, 63, 80-92 (2017)

12. Informácia o vývoji zahraničného obchodu Slovenskej republiky $s$ agropotravinárskymi produktmi za rok 2017. Retrieved 20.06.2019 from http://www.mpsr.sk/index.php?navID=759\&navID2=759\&sID=111\&id=13022

13. Informácia o vývoji zahraničného obchodu Slovenskej republiky $\mathrm{s}$ agropotravinárskymi produktmi za rok 2017. Príloha č.2 - 2017 Teritoriálna štruktúra. Retrieved 20.06.2019 from http://www.mpsr.sk/index.php?navID=759\&navID2=759\&sID=111\&id=13022

14. N. Jankelova, D. Masar, S. Moricova, Risk factors in the agriculture sector. Agricultural Economics - Zemedelska ekonomika, 63, 247-258 (2017)

15. P. Serences, Z. Cierna, A. Piterkova, The development of value added and net income of farms in Slovakia. Proceedings of International scientific conference: International Scientific Days (ISD) Conference on Agri Food Value Chain - Challenges for Natural Resources Management Society, 378-388 (2016) 